\title{
GEOGRAPHIC VARIATION IN THE CAVE BEETLE \\ NEAPHAENOPS TELLKAMPFI \\ (COLEOPTERA: CARABIDAE)
}

\author{
By Thomas C. Kane ${ }^{1}$ and George D. Brunner \\ Department of Biological Sciences, University of Cincinnati \\ Cincinnati, OH 45221 USA
}

\section{INTRODUCTION}

More than 200 species of cave limited (i.e., troglobitic) trechine carabid beetles are known from caves of the eastern United States (Barr, 1979b, 1981). These species are generally considered to be derived from ancestral surface species which were widespread during the cold, moist climates associated with glacial maxima (Barr, 1968). Subsequent warming and drying of these regions, as glaciers retreated, led ultimately to the extirpation of surface populations, with only some of the cave limited stocks surviving. Available evidence suggests that for trechines cave isolation is irreversible (Barr, 1968, 1979a). Therefore, geographic spread of and gene flow in troglobitic trechines will be restricted to subterranean routes (Barr, 1968). The interconnectivity of caves and the presence of geological barriers (e.g., noncavernous strata and large rivers) become important factors in determining the geographic extent of and degrees of gene flow within these troglobitic taxa.

In extensive and highly continuous limestone cave systems, such as those of the Mississippian plateaus, interpretation of evolutionary relationships between closely similar taxa becomes especially complicated (Barr, 1979b). One question which arises is whether such taxa represent multiple isolations of a common surface dwelling ancestor or are the product of more recent divergence in a common troglobitic ancestor. Even when the latter scenario appears to be the case, divergence may only involve subtle, although generally consistent, differences in minor morphological characters. Thus, inferences about such factors as the amount of gene flow, if

'Author to whom all editorial correspondence and reprint requests should be addressed.

Manuscript received by the editor March 25, 1986. 
any, still occurring among the taxa, the relative degree of differentiation between the various taxa, and the manner in which the present geographic pattern has been produced may be strengthened by the availability of genetic data such as those obtained through gel electrophoresis (Barr, 1979b; Turanchik and Kane, 1979).

As Barr (1979b) has indicated, the large geographic distribution and abundance of Neaphaenops tellkampfi populations present an excellent opportunity to assess the extent of gene flow between local populations of a troglobitic trechine using both morphological and electrophoretic data. Among the many species of troglobitic trechine carabid beetles in the United States, Neaphaenops tellkampfi is noteworthy for having the most extensive geographic range and being one of the most abundant species of the group (Barr, 1979b, 1981). The species is distributed (Fig. 1) from just south of the Ohio River in the north to its southern limit near the Tennessee border, in the highly cavernous Mississippian limestones of the Pennyroyal Plateau in west central Kentucky (Barr, 1979b). The western extent of its range is delimited by the noncavernous Big Clifty sandstone, and the eastern and southeastern limits of the range correspond roughly with the contact with the Salem and Warsaw limestones (Barr, 1979b).

Neaphaenops tellkampfi, like other cave trechines, is an important predator in terrestrial cave communities (Barr and Kuehne, 1971; Kane and Poulson, 1976). Unlike other troglobitic trechines in the Pennyroyal Plateau, however, N. tellkampfi has evolved specialized behaviors which allow it to prey on the eggs and early instar nymphs of the common cave "cricket" Hadenoecus subterraneus (Orthoptera: Rhaphidophoridae), resources which are energy rich and seasonally abundant (Kane and Poulson, 1976; Hubbell and Norton, 1978). This predator-prey interaction has evolved to the extent that no $N$. tellkampfi populations occur outside the range of H. subterraneus (Hubbell and Norton, 1978). In fact, Barr (1979b) has suggested that at least part of the eastern limits of the $N$. tellkampfi range may be determined by the absence of $H$. subterraneus further east, rather than to the presence of any extrinsic geological barrier.

Using morphological and geological criteria, Barr (1979b) has recognized four subspecies of $N$. tellkampfi. The nominate subspecies, $N$. t. tellkampfi, on which most of the ecological studies dis- 


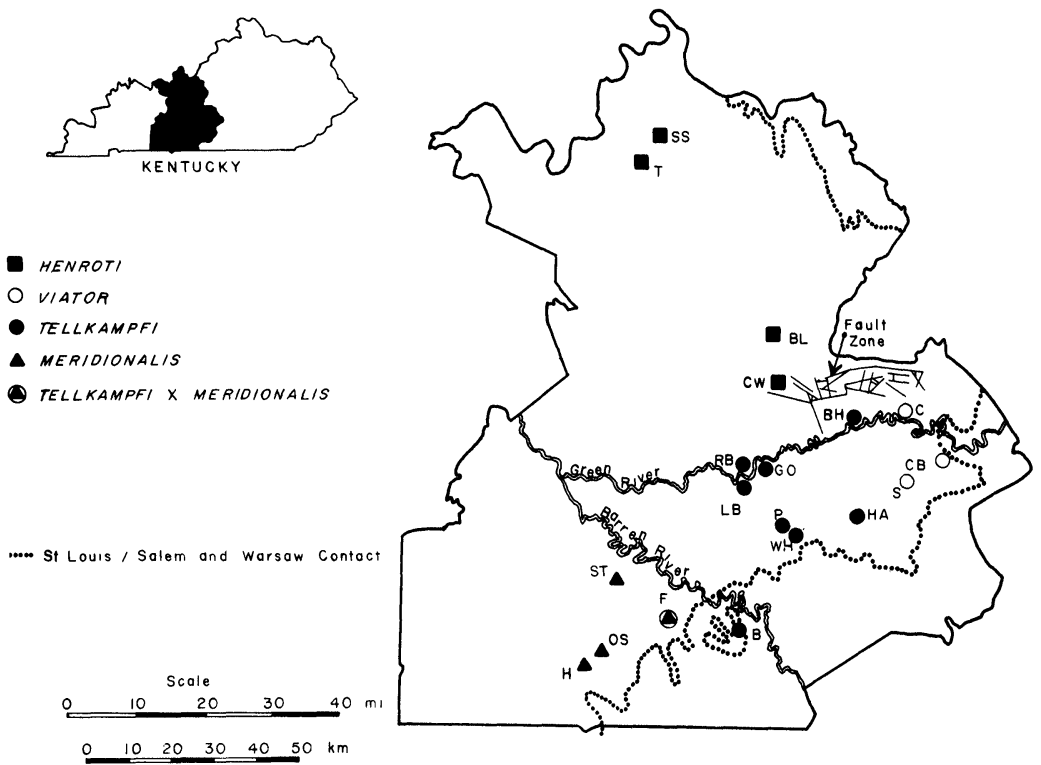

Figure 1. Map of west central Kentucky showing locations sampled for Neaphaenops tellkampfi in this study. Taxonomic designations of populations at these sites (after Barr, 1979b) are as follows: $N$. t. henroti: $\mathrm{BL} ; \mathrm{CW} ; \mathrm{SS} ; \mathrm{T} ;$ N. t. meridionalis: H; OS; ST; N. t. tellkampfi: B; BH; GO; HA; LB; P; RB; WH; $N$. t. viator: C; CB; S; $N$. t. meridionalis $\times N$. t. tellkampfi hybrid: $\mathrm{F}$.

cussed previously have been done, is distributed in the central portion of the range to include the caves of Mammoth Cave National Park. Neaphaenops t. meridionalis, the southern subspecies, is limited to the north by the noncavernous sandstones near the Barren River. However, two populations are known in the southeastern part of the range which are morphologically intermediate between nominate tellkampfi and meridionalis for six of nine diagnostic characters, suggesting a narrow zone of hybridization between the two subspecies. Barr (1979b) points out, however, that despite the limited gene flow, meridionalis is morphologically the most distinct of the four subspecies. Morphological evidence (Barr, 1979b) suggests a broad zone of hybridization between nominate tellkampfi and the eastern subspecies $N$. $t$. viator, with gradual intergradation between the two subspecies over approximately an 
eight $\mathrm{km}$. distance. The eastern extent of the viator range is delimited by the contact of the St. Louis/Salem and Warsaw limestones and, perhaps more directly, by the absence of $H$. subterraneus further east (Barr, 1979b). As is the case with nominate tellkampfi, populations of viator are known from caves on both the north and south sides of the Green River. The northern limits of the viator range are set in large part by a sandstone ridge and extensive fault zone across Hart County. This geological feature also appears to be a complete barrier to gene flow between the northern subspecies $N$. t. henroti and either nominate tellkampfi or viator to the south (Fig. 1) (Barr, 1979b). Despite the absence of any known hybrid populations, tellkampfi and henroti are the most similar subspecies morphologically, and henroti also shows a large degree of morphological affinity with viator as well (Barr, 1979b).

Previous studies using gel electrophoresis (Giuseffi et al., 1978; Turanchik and Kane, 1979) have shown that genetic variability in local populations of $N$. t. tellkampfi approach those observed in similar surface dwelling invertebrates. These results, coupled with similar subsequent findings in other species (e.g., Dickson et al., 1979), suggest that cave adaptation does not necessarily result in a reduction in genetic variation. Further, genetic similarity values (I) (Nei, 1972) among eight local populations of nominate tellkampfi fall in the range (i.e., 0.90-1.00 (Turanchik and Kane, 1979)) commonly reported for populations of continuously distributed surface dwelling species. These results substantiate the contention that continuous limestone expanses can act as underground dispersal highways for cave limited species (Barr, 1968).

The purpose of the present study was to examine electrophoretically several local populations of each of the other three subspecies of $N$. tellkampfi. We were interested in determining how infrasubspecific variation in these subspecies compared with that of nominate tellkampfi. Further, we wished to use these electrophoretic data to quantitatively assess relationships among subspecies and also to gain some insight to how the present distributional pattern of the species has been produced. In these regards, Barr's (1979b) morphological and biogeographic work provides a model against which the electrophoretic data can be examined. 


\section{MeTHODS}

Electrophoretic data gathered from a total of 18 populations (Fig. 1) of Neaphaenops tellkampfi were analyzed in this study. All of the electrophoretic data for ten of these populations were gathered during the course of the present study, between 1980 and 1983. These ten populations include three each of $N$. $t$. henroti $(\mathrm{BL}, \mathrm{CW}$ and $\mathrm{T} / \mathrm{SS}$; Fig. 1), $N$. t. meridionalis (H, OS and ST; Fig. 1 ) and $N . t$. viator (C, CB and S; Fig. 1) as recognized by Barr (1979b). The tenth population ( $\mathrm{F} ;$ Fig. 1$)$ is a purported meridionalis $\times$ tellkampf $i$ hybrid on morphological grounds (Barr, 1979b). Most, but not all, of the electrophoretic data on the eight populations of $N$. $t$. tellkampfi (B, BH, GO, HA, LB, P, RB and WH; Fig. 1) were collected in 1977-78 and reported by Turanchik and Kane (1979). Modifications of and additions to the nominate tellkampfi data set will be discussed in appropriate sections below. All 18 of the populations sampled, with the exception of the SS and T sites of henroti, represent a single cave location. During the course of the study permission to sample the SS site was rescinded before a sample adequate for complete electrophoretic survey could be obtained. Subsequently the nearby $\mathrm{T}$ site was located but it harbored a much smaller henroti population and failed to yield a large enough sample to obtain data on all electrophoretic loci. Pooling of the data from the two sites, which appears to be justified by their geographic proximity, did produce a complete set of electrophoretic data.

Beetles were maintained alive at $5^{\circ} \mathrm{C}$ or frozen at $-80^{\circ} \mathrm{C}$ prior to electrophoresis. All electrophoresis was conducted on vertical polyacrylamide slab gels using an. Ortec Model 4200 Electrophoresis System or a Hoefer Scientific SE600 System. Sample preparation and run procedures used in this study were similar to those discussed by Giuseffi et al. (1978) and Turanchik and Kane (1979). Each animal provided enough homogenate for two assays.

Six enzyme systems provided a total of seven consistently scorable loci. These included: alkaline phosphatase (ALP) (1); esterase (EST) (1); malate dehydrogenase (MDH) (2); phosphoglucomutase (PGM) (1); phosphoglucose isomerase (PGI) (1); and, xanthine dehydrogenase $(\mathrm{XDH})(1)$. In addition a general protein (GP) stain revealed two sets of consistently scorable bands which are also 
included in the data. The more complete data of this study suggested interpretational changes at two loci from those reported by Turanchik and Kane (1979). The present data show that the ALP bands are properly interpreted as a single variable locus rather than as two separate loci. Also, we have chosen a more conservative interpretation of the XDH data. Electrophoretic analysis of XDH in N. tellkampfi populations produces a single band per beetle with slight differences in mobility between some individuals. Initially these data appeared to be consistent with data reported by Singh et al. (1976) for a variable XDH locus in Drosophila pseudoobscura. However, application of additional techniques which Singh et al. (1976) used to reveal multiple bands in $D$. pseudoobscura heterozygotes, failed to reveal any multiple banded $N$. tellkampfi individuals at the XDH locus. More recently, Finnerty and Johnson (1979) have shown that data such as these may be the result of post-translational modification of an enzyme encoded by a monomorphic locus. We have chosen this interpretation of the XDH locus in the present study. PGM was not assayed in previous studies of $N$. tellkampfi (Giuseffi et al., 1978; Turanchik and Kane, 1979) and therefore populations of $N$. $t$. tellkampfi were re-collected and surveyed for this enzyme. The majority of the data analysis was accomplished using a Fortran 77 version of the BIOSYS-1 program developed by Swofford and Selander (1981).

\section{RESULTS}

Of the nine putative genetic loci examined in this study, five were polymorphic and the remaining four were monomorphic with the same variant fixed in all populations of the four taxa (Table 1). Genetic variability in $N$. tellkampfi populations has been estimated as the proportion of polymorphic loci per population $(\mathrm{P})$ and the average frequency of heterozygous loci per individual (H) (Table 2). The average $N$. tellkampfi population is polymorphic at approximately $30 \%$ of its loci and the average individual in such a population is heterozygous at $9.4 \%$ of its loci (Table 2). These values are somewhat lower than those reported previously by Turanchik and Kane (1979) as a result of the addition of another invariant locus (PGM) and the more conservative interpretation of the XDH locus. However, these values of $\mathrm{P}$ and $\mathrm{H}$ still approach values typically reported for many surface invertebrates (Selander, 1976). Therefore, 


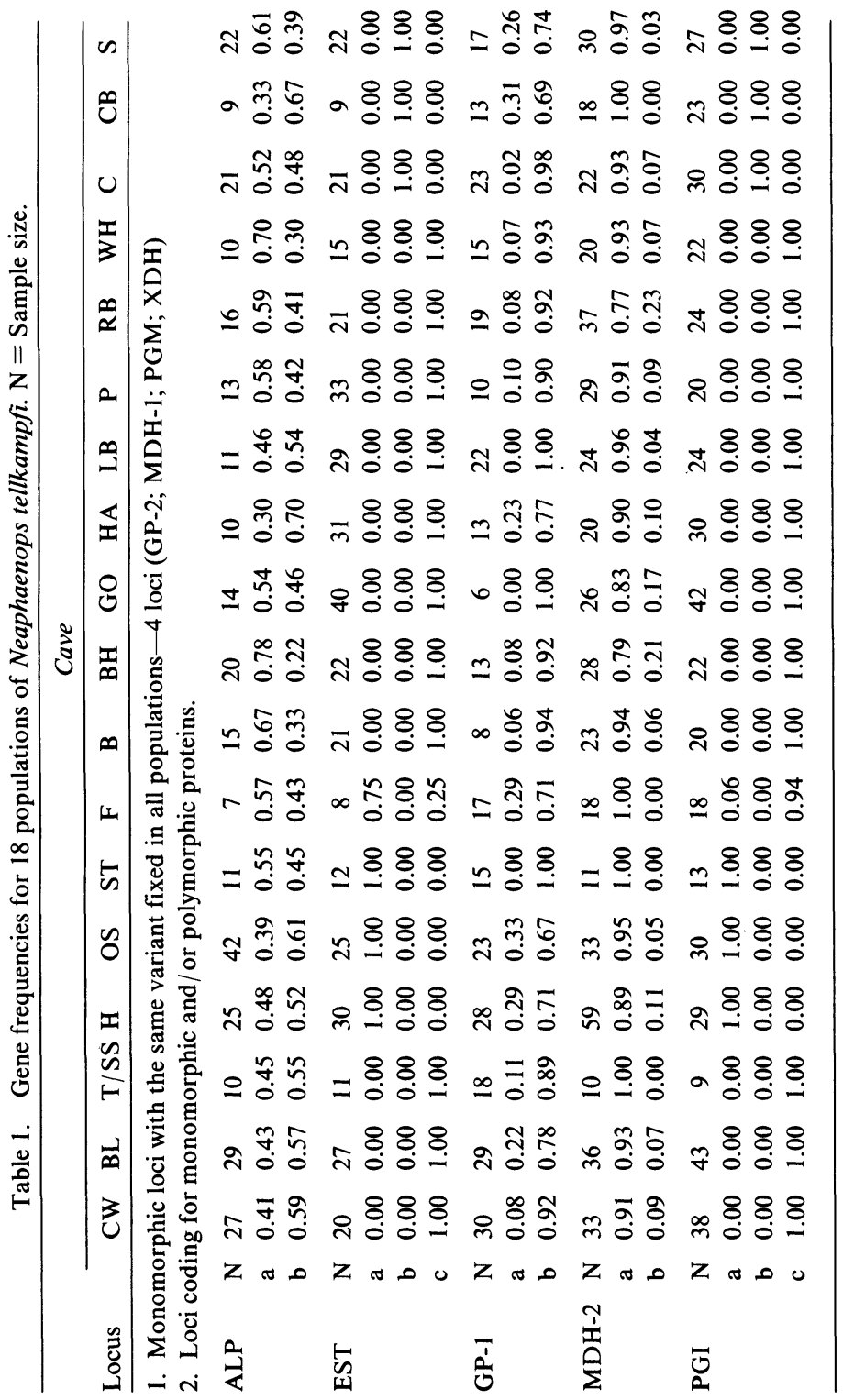


these data continue to support the contention that cave isolation does not necessarily result in a permanent reduction in genetic variability for a species (Barr, 1968; Giuseffi et al., 1978; Dickson et al., 1979; Turanchik and Kane, 1979).

Estimates of $\mathrm{P}$ and $\mathrm{H}$ by subspecies (Table 2 ) indicate no differences in genetic variability between the four taxa. Of the five polymorphic loci examined, two, EST and PGI, are diagnostic of subspecific differentiation (Table 1). Three variants have been detected at each of these loci, with all meridionalis populations fixed for a slow migrating electromorph at both loci, all viator populations fixed for electromorphs of intermediate mobility at each locus, and all henroti and nominate tellkampfi populations being fixed for the fast migrating electromorphs at both loci. The only local population that is polymorphic at these two loci is population F (Fig. 1 and Table 1). This population, which is morphologically intermediate between meridionalis and tellkampfi and a purported hybrid of the two subspecies (Barr, 1979b), contains both the slow and fast electromorphs at both the EST and PGI loci. The fact that these electromorphs are alternatively fixed in meridionalis and tellkampfi populations respectively provides biochemical evidence of the hybrid nature of this population. By contrast, all three of the viator populations are fixed for the intermediate mobility electromorphs at both the EST and PGI loci even though two of these populations, C and $\mathrm{S}$, lie in the zone of morphological intergradation between tellkampfi and viator (Barr, 1979).

Rogers' (1972) estimate of genetic similarity (S) was used for pairwise comparisons of the 18 populations (Table 3 ). Rogers' distance values were used in a UPGMA clustering procedure to produce a biochemical dendrogram (Fig. 2). Infrasubspecific genetic identities are all greater than 0.90 . This includes some populations, such as the $C$ population of viator, separated from other populations of the same subspecies by shallow rivers such as the Green River. This finding is consistent with earlier work (Turanchik and Kane, 1979) on populations BH, RB and B of nominate tellkampfi and with findings on at least one other cave limited species in the same area (Laing et al., 1976), and serves to reconfirm the fact that rivers per se are not necessarily dispersal barriers for cave limited forms. Genetic differentiation between subspecies is substantial in some cases (Fig. 2). Neaphaenops t. meridionalis and N.t. viator 
Table 2. Genetic variability in four subspecies of Neaphaenops tellkampfi. $\mathbf{P}=$ average proportion of polymorphic loci per population; $\mathrm{H}=$ average proportion of heterozygous loci per individual.

\begin{tabular}{|c|c|c|c|c|c|}
\hline \multirow[b]{2}{*}{ Subspecies } & \multirow[b]{2}{*}{ Site } & \multirow[b]{2}{*}{$\mathbf{P}$} & \multicolumn{2}{|c|}{$\mathbf{H}$} & \multirow{2}{*}{$\begin{array}{l}\text { Avg. Alleles/ } \\
\text { Locus }\end{array}$} \\
\hline & & & OBS. & EXP & \\
\hline \multirow[t]{4}{*}{ henroti } & $\mathrm{CW}$ & 0.333 & 0.088 & 0.091 & 1.145 \\
\hline & BL & 0.333 & 0.117 & 0.110 & 1.182 \\
\hline & $\mathrm{T} / \mathrm{SS}$ & 0.222 & 0.091 & 0.081 & 1.187 \\
\hline & AVG & 0.296 & 0.099 & 0.094 & 1.171 \\
\hline \multirow{4}{*}{ meridionalis } & $\mathrm{H}$ & 0.333 & 0.133 & 0.124 & 1.216 \\
\hline & OS & 0.333 & 0.119 & 0.113 & 1.201 \\
\hline & ST & 0.111 & 0.040 & 0.058 & 1.109 \\
\hline & AVG & 0.259 & 0.097 & 0.098 & 1.175 \\
\hline \multirow[t]{9}{*}{ tellkampfi } & B & 0.333 & 0.058 & 0.079 & 1.116 \\
\hline & BH & 0.333 & 0.077 & 0.094 & 1.132 \\
\hline & GO & 0.222 & 0.088 & 0.086 & 1.153 \\
\hline & HA & 0.333 & 0.107 & 0.111 & 1.166 \\
\hline & LB & 0.222 & 0.070 & 0.067 & 1.119 \\
\hline & $\mathbf{P}$ & 0.333 & 0.076 & 0.092 & 1.152 \\
\hline & RB & 0.333 & 0.073 & 0.112 & 1.184 \\
\hline & WH & 0.333 & 0.076 & 0.079 & 1.114 \\
\hline & AVG & 0.305 & 0.078 & 0.090 & 1.142 \\
\hline \multirow[t]{4}{*}{ viator } & $\mathrm{C}$ & 0.333 & 0.093 & 0.075 & 1.132 \\
\hline & CB & 0.222 & 0.101 & 0.102 & 1.171 \\
\hline & $\mathbf{S}$ & 0.333 & 0.101 & 0.104 & 1.177 \\
\hline & AVG & 0.296 & 0.098 & 0.094 & 1.160 \\
\hline \multirow{4}{*}{$\begin{array}{l}\text { mer. } \times \text { tell. } \\
\text { hybrid }\end{array}$} & F & 0.444 & 0.192 & 0.167 & 1.265 \\
\hline & \multicolumn{5}{|c|}{ Neaphaenops tellkampfi } \\
\hline & AVG & 0.302 & 0.094 & 0.097 & 1.162 \\
\hline & OVERALL & 0.556 & & & \\
\hline
\end{tabular}

show levels of similarity to each other and to the other two subspecies in the range of $0.69-0.78$ (Fig. 2). Genetic similarity between henroti and nominate tellkampfi $(\mathrm{S}>0.96$; Table 3$)$ is as great as similarity values among local populations within a subspecies. Although these two subspecies are the most similar of the four 
Table 3. Rogers' (1972) coefficients of genetic similarity (S) for comparisons of four subspecies of Neaphaenops tellkampfi. Values shown are averages of pairwise comparisons of appropriate populations. Values in parentheses are the ranges of similarity values appropriate to each comparison.

\begin{tabular}{|c|c|c|c|c|c|}
\hline \multirow[b]{2}{*}{ Subspecies } & \multirow{2}{*}{$\begin{array}{l}\text { No. of } \\
\text { Pops. }\end{array}$} & \multicolumn{4}{|c|}{ Subspecies } \\
\hline & & N.t.h. & N.t.m. & N.t.t. & N.t.v. \\
\hline henroti & 3 & $\begin{array}{c}0.975 \\
(0.971-0.978)\end{array}$ & & & \\
\hline meridionalis & 3 & $\begin{array}{c}0.748 \\
(0.732-0.766)\end{array}$ & $\begin{array}{c}0.956 \\
(0.942-0.983)\end{array}$ & & \\
\hline tellkampfi & 8 & $\begin{array}{c}0.963 \\
(0.928-0.982)\end{array}$ & $\begin{array}{c}0.730 \\
(0.689-0.763)\end{array}$ & $\begin{array}{c}0.963 \\
(0.917-0.995)\end{array}$ & \\
\hline viator & 3 & $\begin{array}{c}0.741 \\
(0.714-0.758)\end{array}$ & $\begin{array}{c}0.740 \\
(0.727-0.766)\end{array}$ & $\begin{array}{c}0.737 \\
(0.713-0.765)\end{array}$ & $\begin{array}{c}0.963 \\
(0.945-0.984)\end{array}$ \\
\hline $\begin{array}{l}\text { mer. } \times \text { tell } . \\
\text { hybrid }\end{array}$ & 1 & $\begin{array}{c}0.878 \\
(0.863-0.886)\end{array}$ & $\begin{array}{c}0.833 \\
(0.828-0.836)\end{array}$ & $\begin{array}{c}0.865 \\
(0.844-0.883)\end{array}$ & $\begin{array}{c}0.770 \\
(0.750-0.781)\end{array}$ \\
\hline
\end{tabular}

morphologically, this large a genetic similarity is somewhat unexpected given the presence of the Hart Co. Ridge, an apparent geological barrier between these two subspecies.

Genetic differentiation within and between subspecies was examined using F-statistics (Wright, 1978) and a Chi-square contingency analysis of heterogeneity (Workman and Niswander, 1970). Allozyme phenotype frequencies for the 18 populations were used to calculate genetic differentiation (i.e., F-statistics) in a hierarchichal manner (Wright, 1978). The two hierarchical levels are subspecies within species and local populations within subspecies. Since the hybrid $\mathrm{F}$ population could not be unequivocally assigned to either tellkampfi or meridionalis, it was considered as a fifth "subspecies" at that level of the hierarchy. Three loci (ALP; GPT-1; MDH-2) are variable in some or all local populations of each subspecies. Significant heterogeneity in gene frequencies (Chi-square) was observed among N. t. tellkampfi populations at the ALP and MDH-2 loci but not at the GPT-1 locus (Table 4). Significant heterogeneity in gene frequencies at the GPT-1 locus was observed among local populations of viator and among local populations of meridionalis, but no differentiation was observed among local populations of either subspecies at the ALP or MDH-2 loci (Table 4). No heterogeneity in gene frequency was observed among henroti populations at any of 


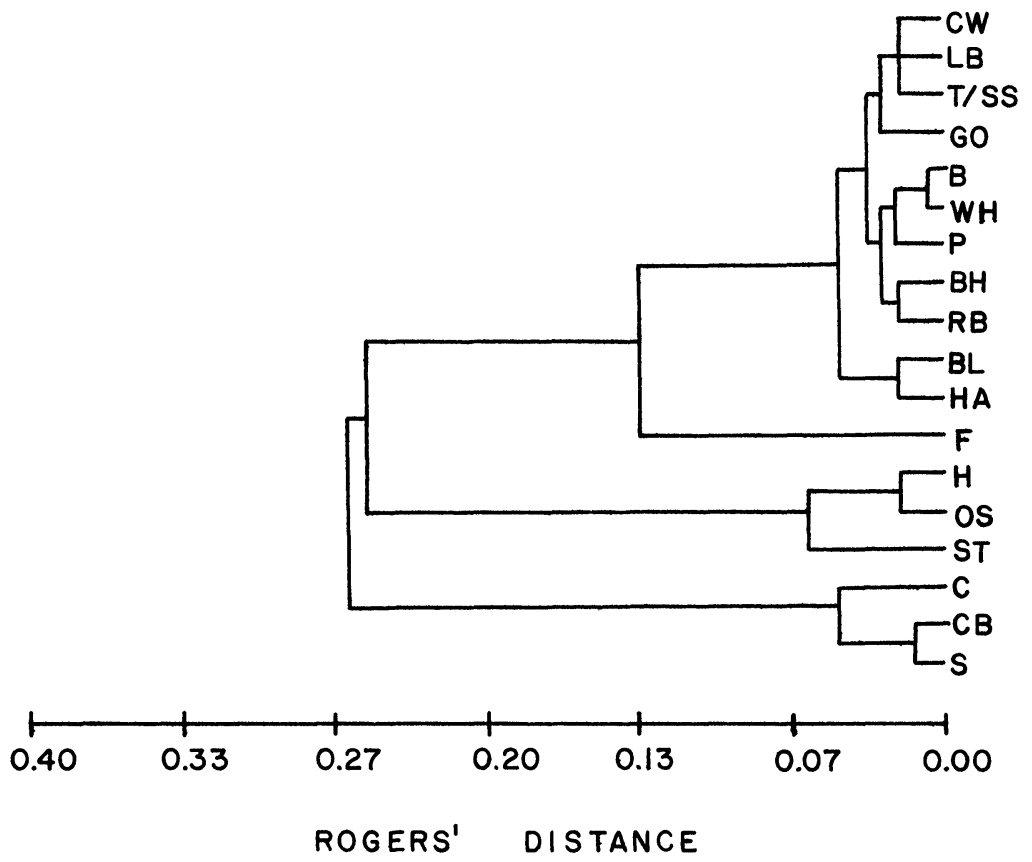

Figure 2. UPGMA dendrogram of 18 populations of Neaphaenops tellkampfi, generated from Rogers' genetic distance values for nine biochemical loci.

the three variable loci. The slightly greater differentiation observed among tellkampfi populations may be due to the fact that this subspecies has a somewhat larger geographic range than any of the other three subspecies, or simply to the fact that more populations (8) were examined for nominate tellkampfi than for any of the other three subspecies.

Whereas genetic differentiation between infrasubspecific populations is slight to moderate, differentiation between subspecies is very great (Table 5). At the level of subspecies, variation is observed at the EST and PGI loci in addition to the three loci discussed above. Significant heterogeneity in allele frequency between subspecies was observed at all five loci (Table 5) and overall genetic differentiation is very great $(F s t=0.528)$, with the EST and PGI loci essentially fixed for alternative alleles in three of the four subspecies. 
Table 4. F-statistics and heterogeneity chi-square values for four subspecies of $N$. tellkampfi.

\begin{tabular}{lcccc}
\hline & $\mathrm{F}_{\mathrm{IT}}$ & $\mathrm{F}_{\mathrm{IS}}$ & $\mathrm{F}_{\mathrm{ST}}$ & $\mathrm{X}^{2}$ \\
\hline SUBSPECIES & \multicolumn{5}{c}{$\mathrm{ALP}$ LOCUS } \\
henroti & -0.007 & -0.013 & 0.006 & $0.510 \mathrm{~ns}$ \\
meridionalis & 0.098 & 0.083 & 0.016 & $1.690 \mathrm{~ns}$ \\
tellkampfi & 0.217 & 0.150 & 0.080 & $16.416^{*}$ \\
viator & -0.183 & -0.201 & 0.015 & $1.291 \mathrm{~ns}$ \\
& & & & \\
& & $\mathrm{GPT}-1$ LOCUS & & \\
henroti & -0.166 & -0.207 & 0.034 & $5.613 \mathrm{~ns}$ \\
meridonalis & -0.004 & -0.154 & 0.130 & $12.145^{* * *}$ \\
tellkampfi & -0.083 & -0.157 & 0.064 & $13.810 \mathrm{~ns}$ \\
viator & 0.193 & 0.105 & 0.098 & $12.465^{* * *}$ \\
& & & & \\
& & $\mathrm{MDH}-2 \mathrm{LOCUS}$ & & $1.958 \mathrm{~ns}$ \\
henroti & -0.007 & -0.089 & 0.006 & $4.549 \mathrm{~ns}$ \\
meridionalis & -0.055 & -0.100 & 0.042 & $17.605^{*}$ \\
tellkampfi & 0.209 & 0.176 & 0.041 & $2.539 \mathrm{~ns}$ \\
viator & -0.034 & -0.058 & 0.022 & \\
& & & & \\
\hline
\end{tabular}

$\mathrm{ns}=\mathrm{P}>0.05 ; *=\mathrm{P}<0.05 ; * * *=\mathrm{P}>0.005$

$\mathrm{F}_{\mathrm{IT}}=$ correlation between uniting gametes relative to the gametes of the total population

$\mathrm{F}_{1 \mathrm{~S}}=$ average correlation over subdivisions of uniting gametes relative to those of their own subdivision

$\mathrm{F}_{\mathrm{ST}}=$ correlation of random gametes within subdivisions relative to gametes of the total population

Slatkin (1981) has proposed a method to estimate overall gene flow in natural populations in a qualitative manner from gene frequency data. Using computer simulation, Slatkin (1981) has demonstrated a dependence between gene flow and the conditional average frequency of an allele, $\overline{\mathrm{p}}(\mathrm{i})$ where:

$\mathbf{d}=$ number of demes sampled

$\mathrm{i}=$ number of demes in which the allele occurs

$\overline{\mathrm{p}}=$ average frequency of the alleles in those demes

Caccone (1985) used Slatkin's technique to assess gene flow in several species of cave animals, based on her own data for $\mathrm{H}$. subterraneus, the data of Laing et al. (1976) for the scavenger beetle Ptomaphagus hirtus and Turanchik and Kane's (1979) data for the 
Table 5. Hierarchichal F-statistics and heterogeneity chi-square analyis of allelic frequencies between subspecies of Neaphaenops tellkampfi

\begin{tabular}{lccrc}
\hline Locus & $\mathrm{F}_{\mathrm{CT}}$ & $\mathrm{F}_{\mathrm{CS}}$ & $\mathrm{F}_{\mathrm{ST}}$ & $\mathrm{X}^{2}$ \\
\hline ALP & 0.022 & 0.023 & -0.001 & $16.224 * *$ \\
EST & 0.958 & 0.000 & 0.958 & $1564.120^{* * *}$ \\
GPT-1 & 0.081 & 0.074 & 0.007 & $22.227^{* *}$ \\
MDH-2 & 0.044 & 0.035 & 0.009 & $17.900^{* *}$ \\
PGI & 0.988 & 0.000 & 0.988 & $1841.171^{* * *}$ \\
TOTAL & 0.546 & 0.038 & 0.528 & \\
\hline
\end{tabular}

$* *=\mathrm{P}<0.01 ; * * *=\mathrm{P}<0.005$

$\mathrm{F}_{\mathrm{CT}}=$ correlation of random gametes in local populations relative to the gametes of the total population

$\mathrm{F}_{\mathrm{CS}}=$ average correlation over subspecies of uniting gametes relative to those of their own subspecies

$\mathrm{F}_{\mathrm{ST}}=$ correlation of random gametes within subspecies relative to gametes of the total population

subspecies $N$. t. tellkampfi. Thus, an analysis of gene flow in all four $N$. tellkampfi subspecies is appropriate since both $H$. subterraneus and $P$. hirtus are sympatric with $N$. tellkampfi. Further, the range of H. subterraneus examined by Caccone (1985) is more comparable to that of $N$. tellkampfi (s.l.) than simply to that of nominate tellkampfi.

The Slatkin analysis suggests that $N$. tellkampfi may be qualitatively described as a species in which gene flow level is low. Alleles with low incidence values (i/d) have high conditional frequencies $(\overline{\mathrm{p}})$ (Fig. 3). Caccone (1985) showed that $P$. hirtus is also a species with low gene flow levels. By contrast, $H$. subterraneus is seen to be a species with intermediate gene flow levels (Caccone, 1985). As indicated earlier, the range of $H$. subterraneus is larger than and includes the entire range of $N$. tellkampfi. Unlike $N$. tellkampfi and $P$. hirtus, however, H. subterraneus is troglophilic (facultative cave dweller) and thus is capable of some dispersal on the surface in addition to the subterranean routes available to troglobites. Analysis of the eight nominate tellkampfi populations indicates a high level of gene flow within this subspecies (Fig. 3) despite some heterogeneity in gene frequencies among these populations (Table 4). The overall pattern of gene flow is generally consistent with the pattern of genetic differentiation obtained from the F-statistics. 


\section{Discussion}

The patterns of variation described here for N. tellkampfi provide a basis for understanding some of the factors which cause genetic differentiation in cave limited species. Barr (1979b) suggested that three different patterns of gene flow were indicated by the morphological and geological data on the four subspecies. These include: (1) no gene flow (henroti with either tellkampfi or viator); (2) very limited gene flow (meridionalis with tellkampfi); and, (3) moderate gene flow (tellkampfi with viator). Initially the biochemical data seem to support only pattern (2) with population F clearly containing meridionalis $\times$ tellkampf $i$ hybrids and with other meridionalis and tellkampfi populations examined in this study showing no biochemical evidence of hybridization. Thus, the morphological data (Barr, 1979b) and now the biochemical data suggest that hybridization is restricted to a very narrow geographic area.

The allozyme data directly support only part of pattern (1). The relatively large genetic distance between henroti and viator $(\mathrm{D}=0.289)$ and the lack of any biochemical, as well as morphological (Barr, 1979b), evidence of hybridization support the assertion that the Hart Co. Ridge is acting as a complete barrier to gene flow between these two subspecies. The large genetic similarity between henroti and tellkampfi $(\mathrm{S}>0.96)$ does not lend support to the conclusion that these two subspecies are also extrinsically isolated from each other. However, allozyme studies on the scavenger beetle $P$. hirtus (Laing et al., 1976) show that a population north of the Hart Co. Ridge has a genetic similarity (I) of approximately 0.75 with two populations south of the Ridge in caves GO and RB, which are also occupied by nominate tellkampfi. Further, the Hart Co. Ridge coincides with the southern range limit of Orconectes inermis (Decapoda: Astacidae) and the northern range limit of $O$. pellucidus, two species of troglobitic crayfish whose ranges are almost completely separate (Hobbs and Barr, 1972). Thus the evidence for the Hart Co. Ridge as a dispersal barrier is overwhelming.

The close genetic similarity between henroti and tellkampfi is consistent with Barr's (1979b) supposition that all four subspecies of $N$. tellkampfi are descended from a common ancestral stock that became isolated in caves in the southern portion of the present range. Barr argues that henroti was derived from a peripheral population of nominate tellkampfi which penetrated north of the Hart 


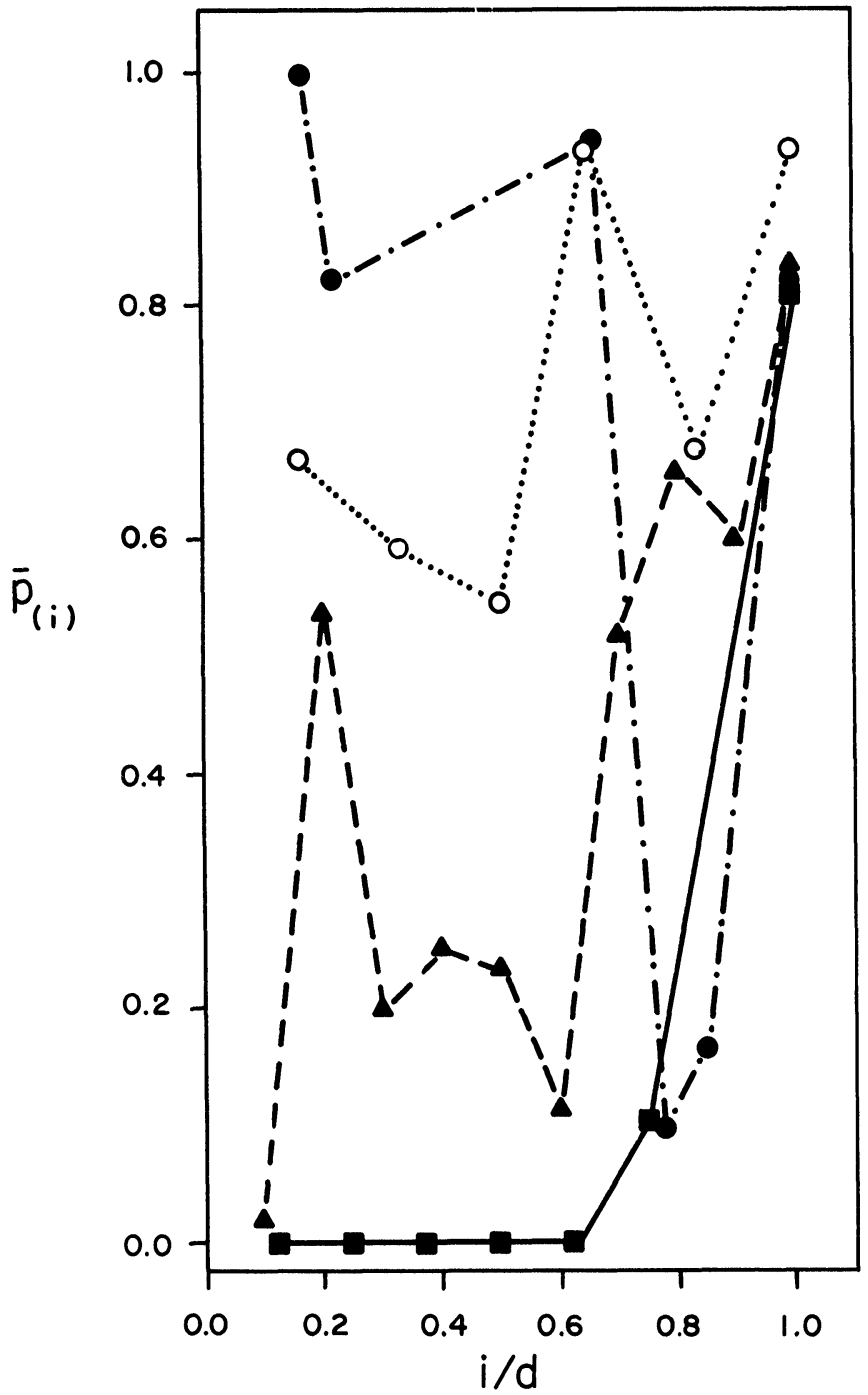

Figure 3. Conditional allele frequencies $(p(i))$ as a function of their incidence (i/d) in four taxa of cave-dwelling organisms. Three qualitative patterns of gene flow are inferred: low gene flow: Neaphaenops tellkampfi (filled circles) and Ptomaphagus hirtus [open circles (data from Laing et al., 1976)]; intermediate gene flow: Hadenoecus subterraneus [triangles (data from Caccone, 1985)]; and, high gene flow: Neaphaenops tellkampfi tellkampfi (squares). 
Co. Ridge through some of the scattered cave systems known in the area. The close biochemical similarity of henroti and tellkampfi support this view over the alternative hypothesis that henroti represents a separate isolation of the surface dwelling ancestral species. Furthermore, Barr (1979b) notes that henroti has apparently not extended its range as far northward and westward as the geological evidence and the distribution of Hadenoecus subterraneus would suggest is possible. This observation, coupled with the evidence of high genetic similarity between henroti and tellkampfi, is supportive of a southern origin for $N$. tellkampfi with the range of henroti representing the most recent northward dispersal.

The allozyme data fail to demonstrate a broad zone of hybridization between tellkampfi and viator (pattern (3) above). Moreover, inclusion of additional information fails to explain the discrepancy between the biochemical distinctness of the two taxa, on the one hand, and the independent evidence for a broad zone of hybridization on the other. The lack of any geological barrier between tellkampfi and viator and the large degree of morphological intergradation between the two taxa (Barr, 1979b) give great support to the hypothesis of hybridization. Two of the viator populations examined in this study (i.e., $\mathrm{C}$ and $\mathrm{S}$ ) lie within the zone of morphological intergradation, making the lack of biochemical hybridization even more puzzling.

Genetic differentiation in $N$. tellkampfi occurs primarily between subspecies, with high genetic similarity $(\mathrm{S}>0.90)$ and only slight $($ Fst $<0.05)$ to moderate $(0.05<$ Fst $<0.15)$ genetic differentiation among infrasubspecific populations. Culver (1982) reanalyzed Laing et al.'s (1976) data on P. hirtus and found that the average between area Nei index for $P$. hirtus populations in the ranges of different $N$. tellkampfi subspecies was I $=0.794$. The average I between $N$. tellkampfi subspecies from the present study is 0.791 . Further, analysis based on conditional allele frequencies indicates that gene flow level in both species can be qualitatively described as low. Interestingly the two species differ greatly in their ecological and demographic characteristics (Kane, 1982) and a substantial amount of evidence suggests that $N$. tellkampfi has a longer evolutionary history of cave isolation than does $P$. hirtus (Laing et al., 1976; Barr, 1979b).

Caccone (1985) suggests that gene flow levels and degree of genetic differentiation in cave species may be influenced by their 
degree of dependence on the cave environment. Troglobitic species such as $N$. tellkampfi and $P$. hirtus, which are restricted to subterranean routes of dispersal, might be expected to show lower gene flow levels and greater genetic differentiation than cave dwelling species which are still capable of some dispersal on the surface. Although its distribution is restricted to cave regions, $H$. subterraneus emerges from caves on warm humid evenings to feed. Thus, the intermediate levels of gene flow inferred for $H$. subterraneus, as opposed to low levels for the two troglobites, may result from limited surface dispersal. Morphological evidence (Hubbell and Norton, 1978) also suggests a lesser degree of geographic differentiation in $\mathrm{H}$. suberraneus than in $N$. tellkampfi over approximately the same area. Morphological differences occur between southwestern populations of $H$. subterraneus (i.e., in the range of $N$. t. meridionalis) and those to the north. However, there is no significant morphological differentiation among the northern populations of $H$. subterraneus (Hubbell and Norton, 1978), whereas in the same region N. tellkampfi is morphologically differentiated into three distinct subspecies (i.e., henroti, tellkampfi and viator). Trogloxenes show less cave dependence than troglophiles. Such species often use caves only sporadically and only for shelter. Unfortunately no genetic data are available for trogloxenes which are partially or wholly sympatric with the species described above. Caccone (1985) does report genetic data for Euhadenoecus puteanus, a relative of $\boldsymbol{H}$. subterraneus, which is a forest dweller and a sporadic trogloxene over a range from southern New York to Georgia. She finds relatively high levels of gene flow between five cave populations of E. puteanus which is at least consistent with the expectations for a trogloxene.

Although degree of cave dependence appears to play a major role in determining the degree of gene flow and genetic differentiation over the geographic range of cave dwelling species, ecological differences between species may also influence their genetic characteristics. Neaphaenops tellkampfi and $P$. hirtus are both troglobites and show similar biogeographic patterns of genetic differentiation. However, ecologically the two species are dissimilar. Whereas $N$. tellkampfi is a specialized predator which tends to establish large permanent populations (Kane and Ryan, 1983), P. hirtus is more opportunistic. Local populations may develop on small isolated patches of organic matter such as carrion or feces from reproduction by a few founders (Peck, 1973) and such populations are often 
ephemeral. Thus, stochastic events may have a greater influence on the genetic characteristics of local $P$. hirtus populations than on those of $N$. tellkampfi. In fact, genetic variability in local $P$. hirtus populations $(\mathrm{P}=0.154 ; \mathrm{H}=0.048$ (Laing et al., 1976) $)$ appears to be about half that of local $N$. tellkampfi populations $(\mathrm{P}=0.302$; $\mathrm{H}=0.094)$. Further, the average Nei index between local $P$. hirtus populations in the range of $N$. t. tellkampfi is $\mathrm{I}=0.874$ (Culver, 1982), whereas the average I between local nominate tellkampfi populations is 0.981 . Thus, if ecological differences influence genetic patterns of similarly cave dependent species, the effects appear to be manifested at the level of local populations.

\section{ACKNOWLEDGMENTS}

We would particularly like to thank Dr. Thomas C. Barr, Jr. for valuable discussions throughout the study, including a critical review of the manuscript. In addition, Dr. Barr kindly provided us with locations for several of the cave sites and in one case (ST site) provided us with material for electrophoresis. We would also like to acknowledge and thank Curtis Meininger for field assistance and useful discussions and Kevie Vulinec for drafting the figures. The National Part Service, Mammoth Cave National Park, KY, kindly provided access to several of the sites used in this study. This research was partially supported by a National Speleological Society Research Grant to GDB and by grants from the American Philosophical Society (Penrose Fund No. 8718) and the National Science Foundation (DEB-8202273) to TCK.

\section{SUMMARY}

An understanding of patterns of geographic variation is important in interpreting evolutionary relationships between closely similar taxa and in inferring levels of gene flow between geographic populations. For obligate cave dwelling (i.e., troglobitic) species, dispersal and gene flow are restricted to subterranean routes. Thus, the interconnectivity of caves and the presence of geological barriers become important factors in determining the geographical distribution and the degree of gene flow among populations of troglobitic species.

Neaphaenops tellkampfi, a troglobitic trechine beetle, has the most extensive geographic range and is one of the most abundant of 
the approximately 200 species of cave trechines in the eastern United States. Four morphological subspecies of $N$. tellkampfi have been described over its range in west central Kentucky. In the present study, electrophoretic data were collected on a total of 18 populations to include all four subspecies. These data support the hypothesis that $N$. tellkampfi has been derived from a single isolation of a surface dwelling ancestor. The present distribution has apparently resulted from a northward movement of the troglobitic stock through subterranean routes. Morphological (i.e., subspecific) differentiation appears to be directly related to the presence of partial and/or complete geological barriers to dispersal in certain portions of the range.

Comparison of genetic data on $N$. tellkampfi with those on other sympatric cave dwelling species suggests that level of gene flow and degree of genetic differentiation may be related to the degree of cave dependence of such species. Troglobites show lower levels of gene flow and greater genetic differentiation over their geographic ranges than do more facultative cave dwellers (e.g., troglophiles and trogloxenes) in which intermediate to high levels of gene flow have been reported. Ecological differences between species with similar degrees of cave dependence do not appear to produce differences in genetic patterns on a biogeographic scale. There is some evidence to suggest, however, that ecological differences between such species may affect genetic variability and genetic distance at the level of local populations.

\section{REFERENCES}

BARR, T. C. 1968. Cave ecology and the evolution of troglobites. In: T. Dobzhansky, M. K. Hecht and W. C. Steere (eds.) Evolutionary Biology, Plenum Press, New York pp. 35-102.

BARR, T. C. 1979a. Revision of Appalachian Trechus (Coleoptera: Carabidae). Brimleyana 2: 29-75.

Barr, T. C. 1979b. The taxonomy, distribution, and affinities of Neaphaenops with notes on associated species of Pseudanophthalmus (Coleoptera: Carabidae). American Museum Novitates: No. 2682 pp. 20.

BARR, T. C. 1981. The cavernicolous carabid beetles of North America. Proceedings of the Eighth International Congress of Speleolology 1: 343-344.

Barr, T. C. AND R. A. Kuehne. 1971. Ecological studies in the Mammoth Cave ecosystem of Kentucky. II. The ecosystem. Annales de Speleolologie 26: 47-96.

CAccone, A. 1985. Gene flow in cave arthropods: a qualitative and quantitative approach. Evolution 39: 1223-1235. 
Culver, D. C. 1982. Cave life: evolution and ecology. Harvard University Press, Cambridge, Mass.

Dickson, G. W., J. C. Patton, J. L. Holsinger and J. C. Avise. $1979 . \quad$ Genetic variability in cave-dwelling and deep-sea organisms with emphasis on Crangonyx antennatus (Crustacea: Amphipoda) in Virginia. Brimleyana 2: 119-130.

FinnerTy, V. AND G. JoHnson. 1979. Post-translational modification as a potential explanation of high levels of enzyme polymorphism: xanthine dehydrogenase and aldehyde oxidase in Drosophila melanogaster. Genetics 91: 695-722.

Giuseffi, S., T. C. Kane ANd W. F. Duggleby. 1978. Genetic variability in the Kentucky cave beetle Neaphaenops tellkampfi (Coleoptera: Carabidae). Evolution 32: 679-681.

HobBs, H. H., JR. AND T. C. BARR. 1972. Origins and affinities of the troglobitic crayfishes of North America (Decapoda: Astacidae). II. Genus Orconectes. Smithsonian Contributions to Zoology: No. 105 pp. 84.

Hubbell, T. H. and R. M. Norton. 1978. The systematics and biology of the cave crickets of the North American Tribe Hadenoecini (Orthoptera Saltatoria: Ensifera: Rhaphidophoridae: Dolichopodinae). Miscellaneous Publications Museum of Zoology, University of Michigan, Ann Arbor: No. 156 pp. 124.

KANE, T. C. 1982. Genetic patterns and population structure in cave animals. In: D. Mossakowski and G. Roth, eds. Environmental adaptation and evolution. Gustav Fischer, Stuttgart, West Germany, pp. 131-149.

Kane, T. C. AND T. L. Poulson. 1976. Foraging by cave beetles: spatial and temporal heterogeneity of prey. Ecology 57: 793-800.

Kane, T. C. AND T. Ryan. 1983. Population ecology of carabid cave beetles. Oecologia (Berlin). 60: 46-55.

Laing, C. D., G. R. Carmody and S. B. Peck. 1976. Population genetics and evolutionary biology of the cave beetle Ptomaphagus hirtus. Evolution 30: 484-498.

NeI, M. 1972. Genetic distance between populations. American Naturalist 106: 283-292.

PeCK, S. B. 1973. A systematic revision and the evolutionary biology of the Ptomaphagus (Adelops) beetles of North America (Coleoptera: Leiodidae), with emphasis on cave-inhabiting species. Bulletin of the Museum of Comparative Zoology (Harvard). 145: 29-162.

Rogers, J. S. 1972. Measures of genetic similarity and genetic distance. Studies in genetics, University of Texas Publications 7213: 145-153.

Selander, R. K. 1976. Genic variation in natural populations. In: F. J. Ayala (ed.) Molecular Evolution, Sinauer, Sunderland, Mass. pp. 21-45.

Singh, R. S., R. C. Lewontin and A. A. Felton. 1976. Genetic heterozygosity within electrophoretic "alleles" of xanthine dehydrogenase in Drosophila pseudoobscura. Genetics 84: 609-629.

SLATKIN, M. 1981. Estimating levels of gene flow in natural populations. Genetics 99: 323-335.

SWOFFord, D. L. AND R. B. SELANDER. 1981. BIOSYS-1: a FORTRAN program for the comprehensive analysis of electrophoretic data in population genetics and systematics. The Journal of Heredity 72: 281-283. 
TuRANChiK, E. J. AND T. C. KANE. 1979. Ecological genetics of the cave beetle Neaphaenops tellkampfi (Coleoptera: Carabidae). Oecologia (Berlin) 44: 63-67.

Workman, P. L. AND J. D. Niswander. 1970. Population studies on southwestern Indian tribes. II. Local genetic differentiation in the Papago. American Journal of Human Genetics 22: 24-49.

WRIGHT, S. 1978. Evolution and the genetics of populations, vol. 4. Variability within and among natural populations. University of Chicago Press, Chicago. 

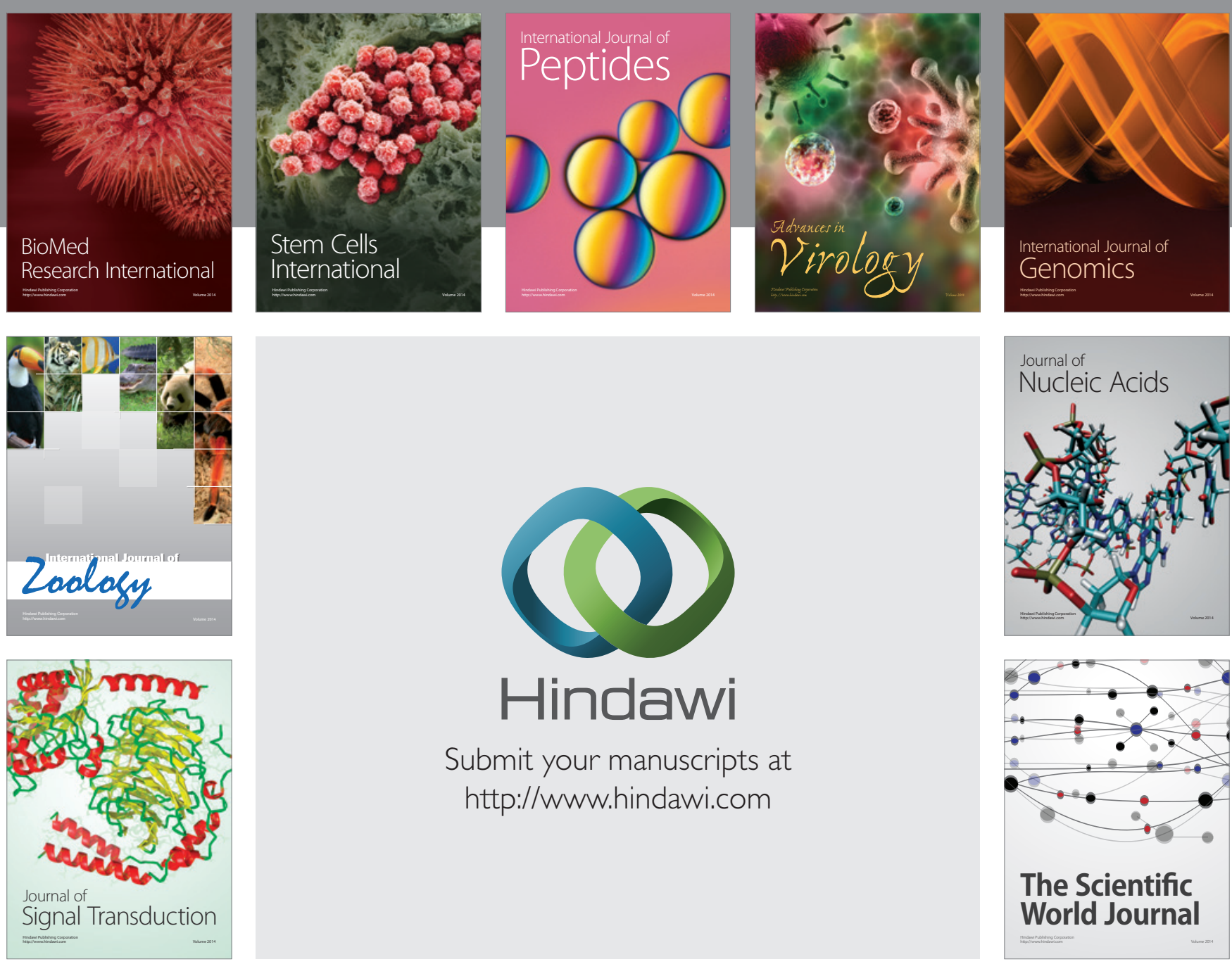

Submit your manuscripts at

http://www.hindawi.com
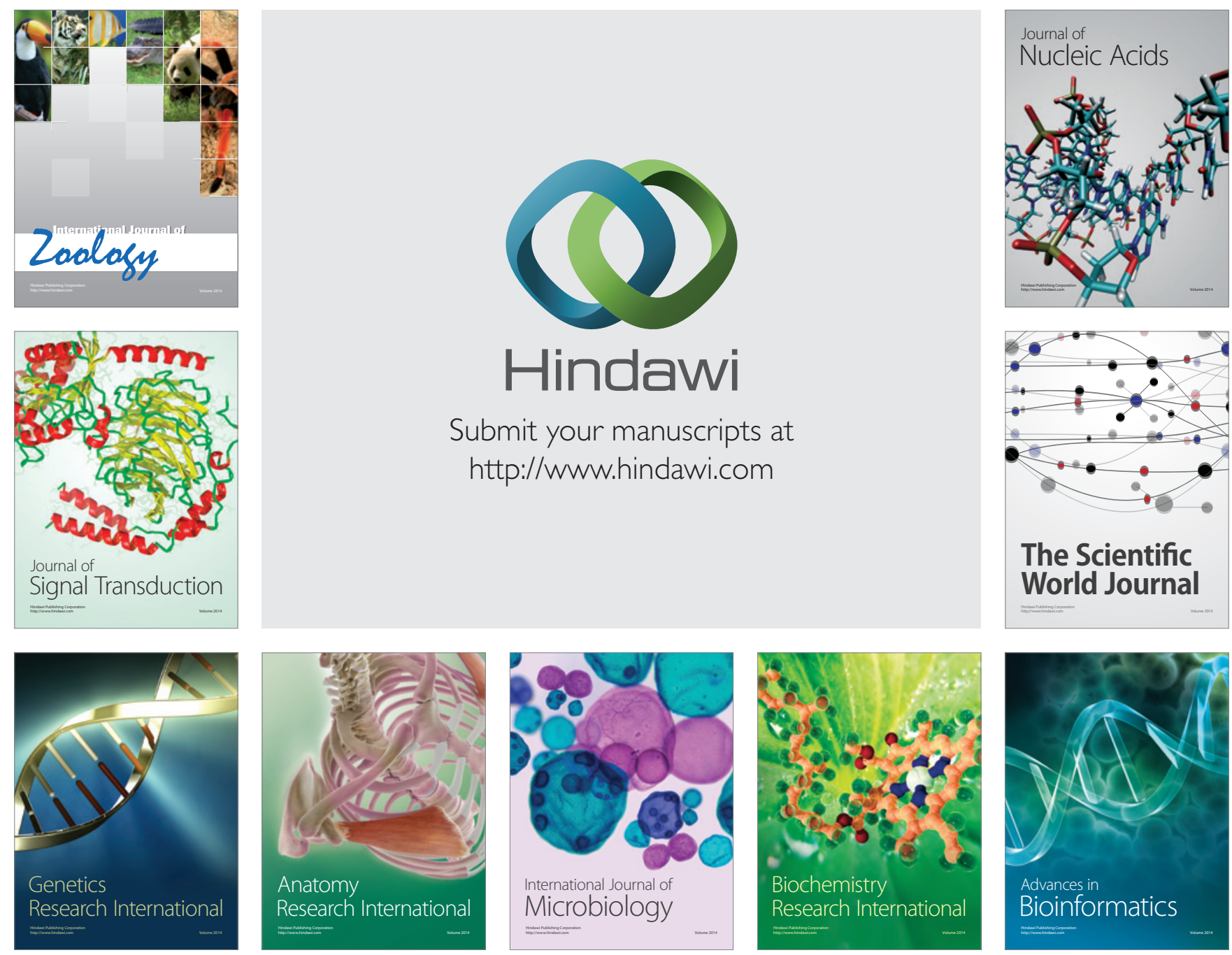

The Scientific World Journal
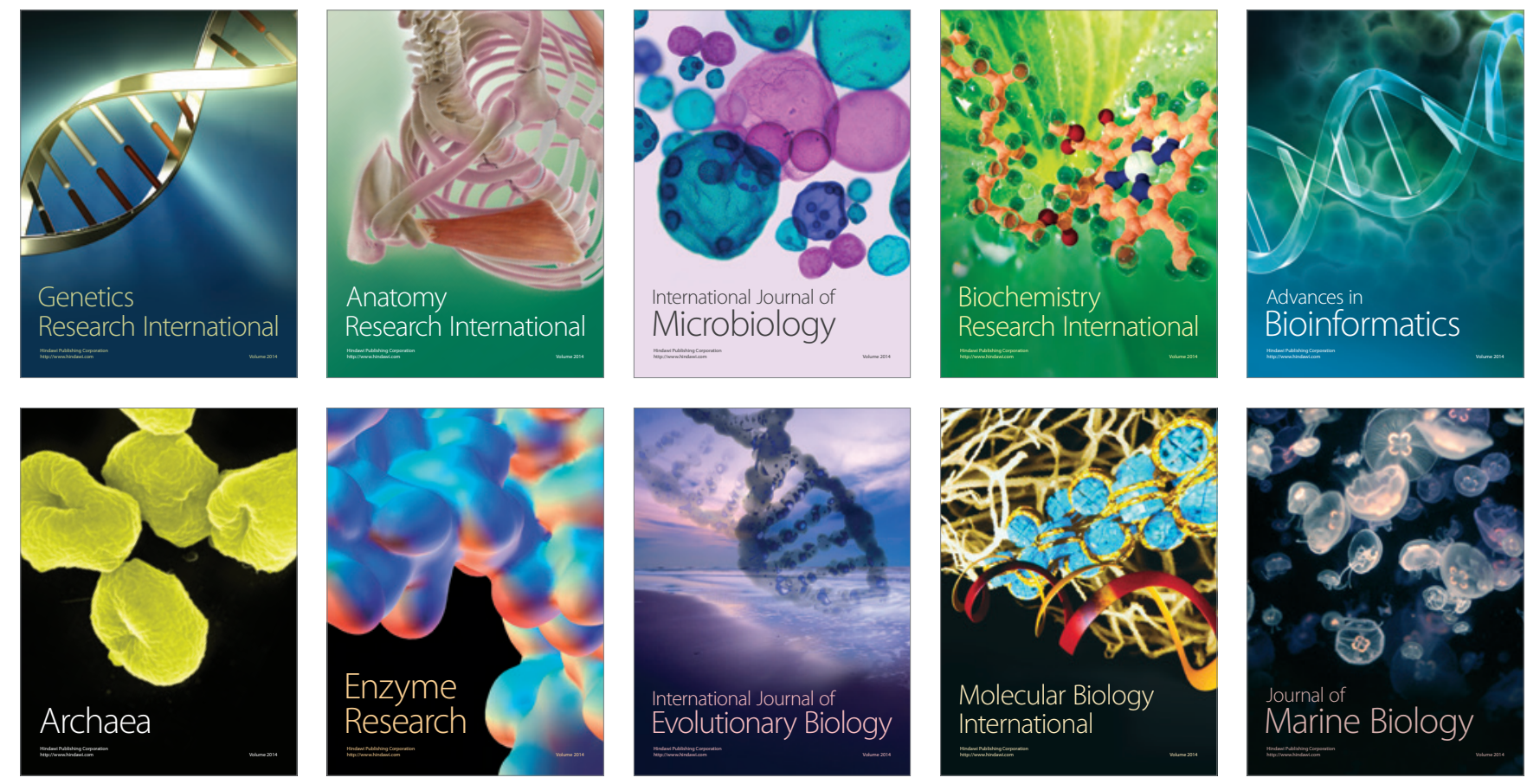